\title{
Dynamics of Heavy Metal Pollution in Tropical lagoon of Gulf of Guinea, West Africa
}

\section{${ }^{* 1}$ ABDUL, WO; ${ }^{1}$ OGUNTUASE, KE; ${ }^{1}$ OMONIYI, IT; ${ }^{2}$ BADA; SB; ${ }^{1}$ ADEKOYA, EO; ${ }^{1}$ BASHIR, AO; ${ }^{1}$ IBEBUIKE, LC; ${ }^{1}$ OPAJOBI, GA}

\author{
${ }^{I}$ Department of Aquaculture and Fisheries Management, Federal University of Agriculture Abeokuta, Nigeria. \\ ${ }^{2}$ Department of Environmental Management and Toxicology, Federal University of Agriculture Abeokuta, Nigeria. \\ *Corresponding Author Email: abdulwo@funaab.edu.ng; Tel: +2348183429107
}

\begin{abstract}
In this study the accumulation of Iron (Fe), Zinc (Zn), Cobalt (Co), Chromium (Cr), Cadmium (Cd), Lead $(\mathrm{Pb})$ and Nickel (Ni) in sediment, water, some fish samples (Schilbe mystus, Mormyrus rume, Gymnarchus niloticus, Cynoglossus senegalensis, and Chrysichthys nigrodigitatus) and an aquatic plant Eichhornea crassipes collected from Lekki lagoon, Lagos Nigeria were examined. Heavy metals in the water, sediment, some selected fish and an aquatic plant were determined seasonally across nine sampling Stations; in the gills, liver and muscles of the fish species and in the root stem and leaves of Eichhornea crassipes using an atomic absorption spectrometer (AAS). Heavy metals concentrations in the sediment and water varied significantly, both spatially and seasonally. Metal concentrations varied between species and body parts while $\mathrm{Co}, \mathrm{Cr}$ and $\mathrm{Pb}$ were not detected. $\mathrm{Ni}$ was found in the liver and gills of S. mystus and M. rume and $\mathrm{Cr}$ in the gills of G. niloticus only. In Eichhornea crassipes, metals detected were in the order: root>leaves $>$ stem for $\mathrm{Fe}, \mathrm{Zn}, \mathrm{Cr}$, and $\mathrm{Cd}$; root>stem>leaves for $\mathrm{Pb}$ and $\mathrm{Ni}$ while $\mathrm{Co}$ was not detected. Heavy metal presence in Lekki Lagoon calls for monitoring of activities within and around the lagoon and policy development towards the sustainable ecosystem health services.
\end{abstract}

DOI: https://dx.doi.org/10.4314/jasem.v23i5.32

Copyright: Copyright $\odot 2019$ Abdul et al. This is an open access article distributed under the Creative Commons Attribution License (CCL), which permits unrestricted use, distribution, and reproduction in any medium, provided the original work is properly cited.

Dates: Received: 03 March 2019; Revised:19 April 2019; Accepted 19 May 2019

Keywords: Pollutants, Heavy metals, Eichhornia crassipes, Bioaccumulation, Lekki lagoon

Aquatic pollution has been an issue of concern over the last few decades as a result of the health hazards it poses to aquatic lives and the human population at large. Pollutants in aquatic ecosystems come from excessive nutrient inputs, eutrophication, acidification, heavy metal contamination, organic pollution, and obnoxious fishing practices (Emmanuel and Chukwu, 2010). Meanwhile, among these pollutants, heavy metal contamination is of particular interest and has attracted the attention of several investigators both in the developed and developing countries of the world (Arena et al., 2013; Kuton et al., 2014). However, the level of pollutants have been on increase through anthropogenic sources such as the increase in human population, urbanization, industrialization, agricultural practices, petroleum contamination and sewage disposal (Santos et al., 2005; Gupta et al., 2009). Heavy metals being a principal pollutant, bio-accumulates in the food chain and makes fish very sensitive to heavy metal pollution (Akan et al., 2012). Fish takes up these metals via food, intake of water through the gills, suspended particulate matter, and sediment, which are then absorbed into different organs or tissues in the body such as the gills, liver, kidney and muscles (Nussey,
2000) causing health hazards when intake is excessively elevated in humans. Sediments play a major role in determining the pattern of pollution in aquatic ecosystems as they serve as depositories and carriers of contaminants including heavy metals (Celo et al., 1999; Li, 2014). Most of these metals are absorbed into the sediment and subsequently released into the water via re-suspension processes such as currents, waves, dredging and other anthropogenic activities (Jonah et al., 2014). Heavy metals are also taken up directly from the sediment by benthic organisms and transferred up the food chain when they are fed upon. Also, aquatic plants have also been reported to accumulate pollutants such as heavy metals thus making them important indicators of heavy metal contamination (Samecka-Cymermanoz, 2005). Heavy metals have been reported to be well concentrated in the water, sediments and biota in lagoons exceeding permissible levels (Don-Pedro et al., 2004), thus representing an unsafe link between the aquatic resources and human health. Similar studies have been carried out by Chindah et al. (2004) and Davies et al. (2006) in Calabar River Estuary and Eleshi Creek with paucity of information on the dynamics of Lekki lagoon. Earlier studies on sediment, water and biota of 
Lake Victoria, Kenya reflected no significant heavy metal pollution [Onyari and Wandiga, 1989) while Ogoyi et al. (2011) reported a high concentration of heavy metals in the sediment compared to water and microalgae in the same lake. Also, Akhiromen and Ogbonne (2018) reported an evidence of heavy metal contamination in Epe axis of Lekki Lagoon in water, sediment and the biota, with a significantly high concentration of zinc, copper and iron in the sediment compared to water and the biota (Macrobrachium vollenhovenii). Ekpo et al. (2013) also reported that the concentrations of heavy metals in bottom sediment were significantly higher $(\mathrm{p}<0.05)$ than those recorded in water samples. Reports from these studies showed the utmost importance of periodically determining the levels of heavy metals in aquatic ecosystems. This will guide in ascertaining the health status of aquatic systems towards sustaining its integrity, thus this study, which focused on examination of bioaccumulation of Zinc, Lead, Cadmium, Chromium, Copper and Cobalt in the water, sediment, water hyacinth (Eichhornia crassipes) and selected fish species in Lekki Lagoon, Lagos Nigeria.

\section{MATERIALS AND METHODS}

Description of the Study Area: This study was carried out in Lekki lagoon a tropical lagoon in the Gulf of Guinea. The lagoon lies between $4^{\circ} 00^{\prime}-4^{\circ} 15^{\prime} \mathrm{E}$ and between $6^{\circ} 25^{\prime}-6^{\circ} 37^{\prime} \mathrm{N}$, with a surface area of about $247 \mathrm{~km}^{2}$ and it is mostly shallow (less than $3.0 \mathrm{~m}$ deep) with a maximum depth of $6.4 \mathrm{~m}$ (Opadokun et al., 2015). It is fed by River Oni in the North-eastern part and Rivers Oshun and Saga in the North-western part (Kuton et al., 2014).
Sampling Location and Sample Collection: Sediment and water samples were obtained in wet and dry seasons in triplicates in all the nine Stations in the study area as shown in Figure 1. Water samples were obtained at a depth of about $0.5 \mathrm{~m}$ and stored in labeled polyethylene bottles. Sediment samples were collected using Van Veen grab and stored in labeled polyethylene bags. Forty samples each of adult Schilbe mystus, Mormyrus rume, Gymnarchus niloticus, Cynoglossus senegalensis, and Chrysichthys nigrodigitatus were collected randomly from fishermen in the study area and stored in sterile polyethylene bags. Samples of Eichhornia crassipes were selected randomly across the water body and transported in polyethylene bags. All samples were kept in ice box and transported to the laboratory.

Sample treatment: In the laboratory, sediment samples were dried at $105{ }^{\circ} \mathrm{C}$, ground and passed through a $2 \mathrm{~mm}$ sieve and as described by Page et al. (1982). Water samples were treated by adding $10 \mathrm{ml}$ concentrated nitric acid to $100 \mathrm{ml}$ of sample. The water samples were than digested as described by Olusola and Festus (2015). Prior to digestion, all the fish samples were washed with running water and dissected with sterile scissors to remove gills, liver and muscles. These were transferred into sterile sample bottles, labelled and kept for digestion. The samples were then digested following the procedure of Muritala et al. (2012). Eichhornia crassipes samples were separated into roots, leaves and stems, oven dried at $65^{\circ} \mathrm{C}$ and homogenized with mortar and pestle and digested using the procedure described by Nazir $e t$ al. (2015). Heavy metal concentrations in all the digested samples were determined using Atomic Absorption Spectrophotometer (AAS).

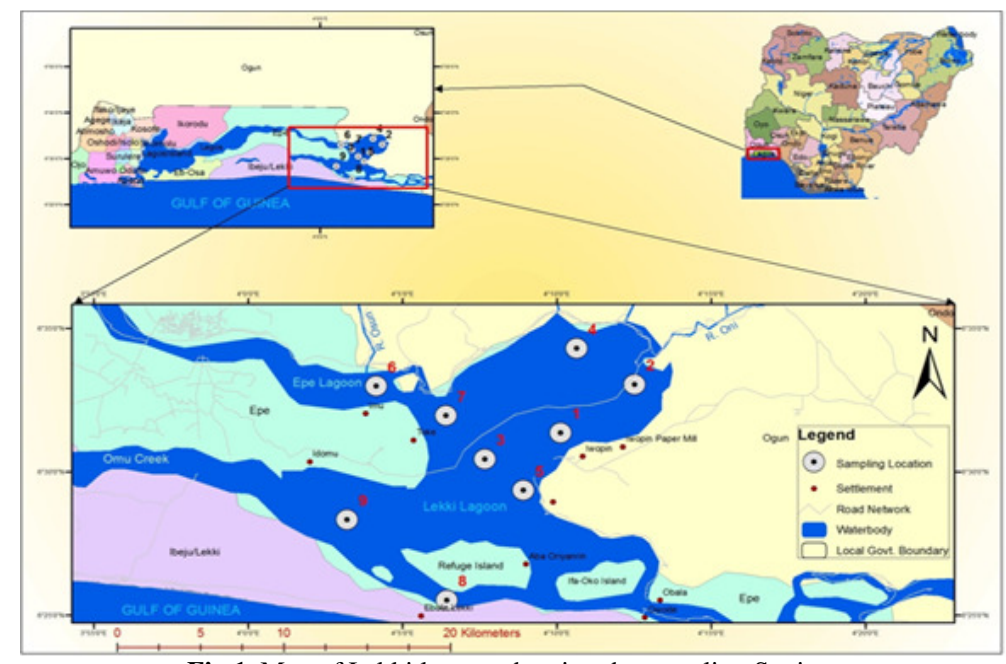

Fig 1. Map of Lekki lagoon showing the sampling Stations

Key: 1=Brushpark, 2=River Oni, 3= Open water, 4=River Mosafejo, 5=Imeki, 6= River Osun, 7=Emina, 8=EbuteLekki, 9=Yuboye. 
Statistical analysis: Data obtained were subjected to descriptive and inferential statistics using Statistical packages for Social Sciences (SPSS version 19.0).

\section{RESULTS AND DISCUSSION}

Sediment is very important tracer of metal in aquatic system (Abeh et al., 2007). The highest concentration $(291.62 \pm 18.16 \mathrm{mg} / \mathrm{kg})$ of Fe was recorded in Station 4 while the least $(81.11 \pm 4.17 \mathrm{mg} . \mathrm{kg})$ was recorded in Station 7. The concentrations of $\mathrm{Zn}$ were $1.02 \pm 0.21 \mathrm{mg} / \mathrm{kg}, 5.27 \pm 0.51 \mathrm{mg} / \mathrm{kg}, 1.98 \pm 0.33 \mathrm{mg} / \mathrm{kg}$, $1.57 \pm 0.12 \mathrm{mg} / \mathrm{kg}, 5.37 \pm 0.13 \mathrm{mg} / \mathrm{kg}, 1.06 \pm 0.03 \mathrm{mg} / \mathrm{kg}$, $0.85 \pm 0.02 \quad \mathrm{mg} / \mathrm{kg}, \quad 1.52 \pm 0.21 \mathrm{mg} . / \mathrm{kg}$ and $5.67 \pm 0.35 \mathrm{mg} / \mathrm{kg}$ in Stations $1-9$ respectively as shown in Table 1. The concentrations of Co were $0.11 \pm 001 \mathrm{mg} / \mathrm{kg}, \quad 0.21 \pm 0.01 \quad \mathrm{mg} / \mathrm{kg} \quad$ and $0.22 \pm 0.01 \mathrm{mg} / \mathrm{kg}$ in Stations 1-3 respectively and other values were below the detection limit in the remaining Stations. The highest and least concentrations of $\mathrm{Cr}$ in the sediment were $1.93 \pm 0.12 \mathrm{mg} / \mathrm{kg}$ and $0.42 \pm 0.02 \mathrm{mg} / \mathrm{kg}$ in Stations 2 and 6 respectively. Also, highest concentrations of $\mathrm{Cd}$ and $\mathrm{Ni}$ were recorded in Station $2(1.87 \pm 0.15 \mathrm{mg} / \mathrm{kg}, 1.74 \pm 0.04 \mathrm{mg} / \mathrm{kg})$ while the least were recorded in Stations $8(0.10 \pm 0.01 \mathrm{mg} / \mathrm{kg})$ and $7(0.54 \pm 0.03 \mathrm{mg} / \mathrm{kg})$ respectively. $\mathrm{Pb}$ values recorded in all Stations were below detection limit. The concentrations of $\mathrm{Cr}, \mathrm{Zn}, \mathrm{Ni}, \mathrm{Cd}, \mathrm{Pb}, \mathrm{Fe}$, and $\mathrm{Co}$ recorded in the sediment in this study were above DPR and WHO maximum permissible limits. Jonah et al. (2014) reported similar high concentrations of these metals in the sediment of Ohii Miri River, Abia State, Nigeria. Table 2 shows that the concentrations of metals were generally higher in the dry season compared to the wet season. Fe recorded the highest concentration of heavy metals in the dry $(183.78 \pm 95.49 \mathrm{mg} / \mathrm{kg})$ and wet $(142.24 \pm 100.30$ $\mathrm{mg} / \mathrm{kg}$ ) seasons while the least concentration were recorded in $\mathrm{Co}$ in the dry season and $\mathrm{Cr}(0.76 \pm 0.21$ $\mathrm{mg} . / \mathrm{kg})$ in the wet season. The highest concentration of $\mathrm{Fe}$ is similar to the findings of Aderionla et al. (2009), who reported that Fe was the most abundant metal in Lagos lagoon (one of the lagoons of the Gulf of Guinea) with a mean value of $482 \pm 8.66 \mathrm{mg} / \mathrm{Kg}$ in the sediment. The high level of Fe in the sediment was also similar in the sediments of the water bodies studied by Asaolu et al. (1997); Asaolu and Olaofe (2004); Nwajei and Gagophien, (2000). Pb was below detectable limit in both seasons in this study which was contrary to the findings of Eddy et al. (2004) who observed a considerable high $\mathrm{Pb}$ values in sediment of River Crossriver.

Table 1: Spatial concentrations heavy metal in the sediment of Lekki lagoon

\begin{tabular}{|c|c|c|c|c|c|c|c|}
\hline \multicolumn{8}{|c|}{ Metals (mg/lg } \\
\hline & Iron & Zine & Cobalt & Chromium & Cadmium & Lead & Nickel \\
\hline 1 & $146.41 \pm 13.15^{6}$ & $1.02 \pm 0.21^{\mathrm{bec}}$ & $0.11=0.01^{b}$ & $1.87 \pm 0.16^{a}$ & $1.16 \pm 0.21^{\mathrm{s}}$ & BLD & $0.78 \pm 0.03^{\mathrm{bc}}$ \\
\hline 2 & $129 . .81 \pm 1 . .20^{\circ}$ & $5.27 \pm 0.51^{=}$ & $0.21 \pm 0.01^{2}$ & $1.93=0.12^{2}$ & $1.87 \pm 0.15^{a}$ & BLD & $1.74 \pm 0.04=$ \\
\hline 3 & $143.51=21.22^{b}$ & $1.98 \pm 0.33^{b}$ & $0.22 \pm 0.01^{2}$ & $0.78=$ & $0.78=0.02^{b}$ & BLD & $0.87 \pm 0.05^{\mathrm{be}}$ \\
\hline 4 & $291.62 \pm 18.16^{=}$ & $1.57 \pm 0.12^{b}$ & BLD & $0.85=$ & BLD & BLD & $1.08 \pm 0.01^{b}$ \\
\hline 5 & $278.01=15.60^{\circ}$ & $5.37 \pm 0.13=$ & BLD & $0.87 \pm 0.01^{b}$ & $0.68=0.04$ & BLD & $0.81=0.04^{\mathrm{be}}$ \\
\hline 6 & $87.21 \pm 9.81^{d}$ & $1.06 \pm 0.03^{\mathrm{bec}}$ & BLD & $0.42 \pm 0.02^{b}$ & BLD & BLD & $0.71 \pm 0.07^{\mathrm{be}}$ \\
\hline 7 & $81.11 \pm 4.17^{d}$ & $0.85 \pm 0.02^{c}$ & BLD & $0.78=0.12^{b}$ & BLD & BLD & $0.54 \pm 0.03^{c}$ \\
\hline 8 & $167.18 \pm 4.11^{b}$ & $1.52 \pm 0.21^{b}$ & BLD & $0.81=0.01^{b}$ & $0.10=0.01$ & BLD & $0.93=0.02^{b}$ \\
\hline 9 & $132 \pm 8.15^{b x}$ & $5.67 \pm 0.35^{2}$ & BLD & $1.28 \pm 0.04^{2}$ & BLD & BLD & $1.72 \pm 0.12^{2}$ \\
\hline
\end{tabular}

*Means with similar superscript across the column indicate there is no significant $(p>0.05)$ difference between means

Detection limit for metals: $\mathrm{Fe}=0.05 \mathrm{mg} / \mathrm{kg}, \mathrm{Zn}=0.005 \mathrm{mg} / \mathrm{kg}, \mathrm{Co}=0.05 \mathrm{mg} / \mathrm{kg}, \mathrm{Cr}=0.04 \mathrm{mg} / \mathrm{kg}, \mathrm{Cd}=0 . \mathrm{mg} / \mathrm{kg}, \mathrm{Pb}=0 . \mathrm{mg} / \mathrm{kg}, \mathrm{Ni}=0.10$ $\mathrm{mg} / \mathrm{kg}$

$B D L$ - Below detection limit

Key: 1=Brushpark, 2=River Oni, 3=Open water, 4=River Mosafejo, 5=Imeki, 6=River Osun, 7=Emina, 8=EbuteLekki, 9=Yuboye

Table 2: Seasonal concentrations heavy metal in the sediment of Lekki lagoon

\begin{tabular}{llllll}
\hline $\begin{array}{l}\text { Metals } \\
\left(\mathbf{m g l}^{-1}\right)\end{array}$ & Dry Season & Wet Season & F (value) p (value) & $\begin{array}{l}\text { DPR (2002)FE PA } \\
\text { (2003) standards for } \\
\text { sed iment }\left(\mathbf{m g h s}^{-1}\right)\end{array}$ \\
\hline Iron & $183.78 \pm 95.49$ & $142.24 \pm 100.30$ & 203 & 0.658 & 20 \\
Zinc & $3.28 \pm 2.56$ & $2.49 \pm 2.29$ & 442 & 0.525 & $50-300$ \\
Cobalt & $0.07 \pm 0.11$ & BLD & 14.64 & 0.010 & 20 \\
Chromium & $1.05 \pm 0.46$ & $0.76 \pm 0.21$ & 2.33 & 0.145 & 0.5 \\
Cadmium & $0.53 \pm 0.07$ & BLD & 11.806 & 0.030 & $0.03-0.3$ \\
Lead & $00 \pm 00$ & $00 \pm 00$ & 0.00 & 0.00 & $2-20$ \\
Nickel & $1.07 \pm 0.56$ & $0.964 \pm 0.37$ & 1.312 & 0.268 & 0.8 \\
\hline \multicolumn{5}{c}{ *Means with $p>0.05$ indicate there is no significant difference }
\end{tabular}


As observed in Table 3, Fe and $\mathrm{Zn}$ concentrations in water were compared with standards which revealed that they were within tolerable limits. $\mathrm{Fe}$ concentrations in water for the sampling Stations were found in the following order: $2>6>4>3>8>7>1>5>9$ (in terms of stations), while that of $\mathrm{Zn}$ followed the order: $4>2>6>8>5>3>7>1>9$. Cr was only detected in Station 9, while $\mathrm{Co}, \mathrm{Pb}, \mathrm{Cd}$ and Nickel all fell below the detection limit in all Stations.

Olusola and Festus (2015) recorded contrary results on the concentrations of $\mathrm{Cr}$, but similar results of $\mathrm{Zn}$ within permissible limits in Ondo coastal waters. Fe, $\mathrm{Zn}$ and $\mathrm{Cr}$ were higher in the dry season $(0.200 \pm 0.03$ $\mathrm{mg} / \mathrm{l}, \quad 0.174 \pm 0.048 \quad \mathrm{mg} / \mathrm{l}, \quad 0.155 \pm 0.041 \quad \mathrm{mg} / \mathrm{l}$ respectively) than during the wet season $(0.153 \pm 0.02$ $\mathrm{mg} / \mathrm{l}, \quad 0.155 \pm 0.041 \mathrm{mg} / \mathrm{l}, \quad 0.022 \pm 0.00 \quad \mathrm{mg} / \mathrm{l}$ respectively). However, $\mathrm{Co}, \mathrm{Cd}, \mathrm{Pb}$ and $\mathrm{Ni}$ all fell below the detection limit (Table 4), and there was no significant $(p>0.05)$ difference in the concentrations of $\mathrm{Fe}, \mathrm{Zn}$ and $\mathrm{Cr}$ in both seasons, while the concentrations of $\mathrm{Fe}$ was less than the acceptable standards. Iron had the highest concentration across Stations compared to other metals recorded in water. This has been previously reported that $\mathrm{Fe}$ is usually more abundant in freshwater environments than other metals as reported by Forstner and Wittman, (1979); Edokpayi et al. (2016).

The analysis of heavy metals in this study, as shown in Table 5, shows the presence of $\mathrm{Zn}$ and $\mathrm{Fe}$ in the liver, gills and muscles for all fish samples, with traces of $\mathrm{Ni}$ in the liver and gills of S. mystus and M. rume and $\mathrm{Cr}$ in the gills of G. niloticus only. $\mathrm{Co}, \mathrm{Cd}$ and $\mathrm{Pb}$ were, however, not detected in all the samples. The highest concentrations of Iron and Zinc were recorded in the livers of $C$. senegalensis $(0.633 \mathrm{mg} / \mathrm{kg})$ and $M$. rume $(1.119 \mathrm{mg} / \mathrm{kg})$.

$\mathrm{Fe}$ concentrations varied in the order: Liver>Gill>Muscle for samples from G. niloticus, $C$. senegalensis and $M$. rume, and in the order: Gills $>$ Muscle $>$ Liver and Gills $>$ Liver $>$ Muscle for $S$. mystus and $C$. nigrodigitatus. Zn, on the other hand, was recorded in the order: Gills $>$ Liver $>$ Muscle in $S$. mystus, G. niloticus and C. nigrodigitatus, while that of $M$. rume followed the order: Liver $>$ Muscle $>$ Gill. Zinc concentrations in $C$. senegalensis were in the order of Gill $>$ Muscle $>$ Liver. The level of accumulation of metals in fish is of high interest because of the potential effects of pollutant on the fish and humans (Burger and Gochfield, 2005). The results showed the presence of varying concentrations of $\mathrm{Fe}$, $\mathrm{Zn}$, in all fish samples and $\mathrm{Cr}$, and $\mathrm{Ni}$ only in some samples while $\mathrm{Co}, \mathrm{Cd}$ and $\mathrm{Pb}$ were below the detection limit in all fish samples. Variation of heavy metals in the fish samples may be a function of the food habits of the fish, tropic status and source of a particular metal and the distance of the fish from the contamination source (Adebayo, 2017).

Taweel et al. (2013) reported similar variation between the heavy metals in the analysed muscle, liver and spleen tissues in Oreochromis niloticus where $\mathrm{Zn}$ and $\mathrm{Fe}$ were higher in species sampled compared to other metals analysed. This could be traced to the presence of these metals as the most abundant of all metals analysed in the sediment and water samples in the study area. Olusola and Festus (2015) observed similar result for the species sampled from the coastal waters of Ondo state. Also, Murtala et al. (2012) observed that the accumulation of the metals $(\mathrm{Cd}, \mathrm{Ni}$, $\mathrm{Cr}, \mathrm{Co}$ and $\mathrm{Pb}$ ) were higher in the gills than muscle of $H$. forskahlii and $H$. bebe occidentalis from Ogun coastal water. (Shukla et al., 2007; Murtala et al., 2012).

The concentrations of heavy metals in $E$. crassipes is shown in Table 6. Fe, $\mathrm{Zn}, \mathrm{Cr}$, and $\mathrm{Cd}$ varied in the order; root $>$ leaves $>$ stem, $\mathrm{Pb}$ and $\mathrm{Ni}$ in the order root>stem>leaves while Co was not detected. $\mathrm{Cd}$ and $\mathrm{Ni}$ were not detected in the stem and leaves of the plant. Figure 2 and 3 also shows the bio-accumulation factors of E. crassipes relative to sediment and water respectively. In the root, the respective bioaccumulation factors of $\mathrm{Fe}, \mathrm{Zn}, \mathrm{Cr}, \mathrm{Cd}, \mathrm{Pb}$, and $\mathrm{Ni}$ relative to the sediment were $0.01,2.45,4.43,2.19$, 0.62 and 1.19. In the stem the bio-accumulation factors were $1.66 \times 10^{-3}, 0.42,2.88,1.51$ for $\mathrm{Fe}, \mathrm{Zn}, \mathrm{Cr}$, and $\mathrm{Ni}$ respectively while the bio-accumulation in leaves for $\mathrm{Fe}, \mathrm{Zn}, \mathrm{Cr}$, and $\mathrm{Cd}$, were $1.85 \times 10^{-4}, 1.74,4.21$, and 0.85 respectively. The BAF in relation to water for $\mathrm{Fe}$, $\mathrm{Zn}$ and $\mathrm{Cr}$ were: $11.44,12.64,110.27 ; 1.52,2.16$, $71.62 ; 5.80,8.95,10.46$ for root, stem and leaves respectively. In this study heavy metal concentrations in E. crassipes were generally higher in the roots followed by the leaves and least in the stem except in the case of nickel which was higher in the stems than in the roots. The high concentration of $\mathrm{Ni}$ in the stem compared to the roots of $E$. crassipes might be because nickel showed low mobility ability in its transport from the root to green parts of the plant (Yabanlı et al., 2014). The high concentration of heavy metals in $E$. crassipes as observed in this study confirms the capability of macrophytes in removing water soluble substances from solution and temporarily immobilizes them within the aquatic system (Materac and Sobiecka, 2017).

Table 3: Spatial concentrations heavy metal in the water of Lekki lagoon 


\begin{tabular}{|c|c|c|c|c|c|c|c|}
\hline \multicolumn{8}{|c|}{ Metals (mg/l) } \\
\hline Stations & Iron & Zine & Cobalt & Chromium & Cadmium & Lead & Nickel \\
\hline 1 & $0.101 \pm 0.03^{\mathrm{e}}$ & $0.057 \pm 0.0^{6}$ & $\mathrm{BDL}$ & $\mathrm{BDL}$ & $\mathrm{BDL}$ & BDL & $\mathrm{BDL}$ \\
\hline 2 & $0.312 \pm 0.11^{2}$ & $0.215 \pm 0.02^{z}$ & BDL & BDL & BDL & BDL & BDL \\
\hline 3 & $0.198 \pm 0.02^{2}$ & $0.101 \pm 0.01^{\mathrm{bc}}$ & BDL & $\mathrm{BDL}$ & BDL & BDL & BDL \\
\hline 4 & $0.126 \pm 0.12^{b}$ & $0.421 \pm 0.03^{a}$ & BDL & $\mathrm{BDL}$ & BDL & BDL & BDL \\
\hline 5 & $0.131=0.02^{b}$ & $0.133 \pm 0.01^{b}$ & $\mathrm{BDL}$ & $\mathrm{BDL}$ & BDL & BDL & BDL \\
\hline 6 & $0.212=0.02^{2}$ & $0.170=0.0^{6}$ & BDL & BDL & BDL & BDL & BDL \\
\hline 7 & $0.178=0.17^{\text {h }}$ & $0.101 \pm 0.0^{x}$ & $\mathrm{BDL}$ & $\mathrm{BDL}$ & BDL & $\mathrm{BDL}$ & BDL \\
\hline 8 & $0.185 \pm 0.02 \mathrm{~s}$ & $0.159=0.04^{b}$ & BDL & BDL & $\mathrm{BDL}$ & $\mathrm{BDL}$ & BDL \\
\hline 9 & $0.107 \pm 0.01^{e}$ & $0.020=0.00^{\circ}$ & $\mathrm{BDL}$ & $0.39=0.02$ & BDL & BDL & BDL \\
\hline
\end{tabular}

*Means with similar superscript across the column indicate there is no significant ( $p>0.05)$ difference between means Detection limit for metals: ${ }^{\prime} \mathrm{Fe}=0.05 \mathrm{mg} / \mathrm{kg}, \mathrm{Zn}=0.005 \mathrm{mg} / \mathrm{kg}, \mathrm{Co}=0.05 \mathrm{mg} / \mathrm{kg}, \mathrm{Cr}=0.04 \mathrm{mg} / \mathrm{kg}, \mathrm{Cd}=0 . \mathrm{Mg} / \mathrm{kg}, \mathrm{Pb}=0 . \mathrm{Mg} / \mathrm{kg}, \mathrm{Ni}=0.10$ $\mathrm{mg} / \mathrm{kg}$

$B D L$ - Below detection limit

Key: 1=Brushpark, 2=River Oni, 3= Open water, 4= River Mosafejo, 5=Imeki, 6= River Osun, 7=Emina, 8=EbuteLekki, 9=Yuboye

Table 4: Seasonal concentrations heavy metal in the water of Lekki lagoon

\begin{tabular}{|c|c|c|c|c|}
\hline Metals $\left(\mathrm{mgl}^{-1}\right)$ & Dry Season & Wet Season & $p$ (value) & $\begin{array}{l}\text { WHO(2008) standards } \\
\text { for water }\left(\mathrm{mgl}^{-1}\right)\end{array}$ \\
\hline Iron & $0.200 \pm 0.03$ & $0.153 \pm 0.02$ & 0.511 & 0.01 \\
\hline Zine & $0.174=0.048$ & $0.155 \pm 0.041$ & 0.572 & 3 \\
\hline Cobalt & $\mathrm{BDL}$ & $\mathrm{BDL}$ & - & - \\
\hline Chromium & $0.052 \pm 0.00$ & $0.022=0.00$ & 0.671 & 0.05 \\
\hline Cadmium & BDL & $\mathrm{BDL}$ & - & 0.003 \\
\hline Lead & BDL & BDL & - & 0.01 \\
\hline Nickel & $\mathrm{BDL}$ & $\mathrm{BDL}$ & - & 0.02 \\
\hline
\end{tabular}

The results of this study also suggest that aquatic plants may facilitate the transportation of metals from sediments up into leaves. These metals are thereby made available to grazing molluscs and, thus, reintroduced into the food web via fish to birds and humans (Sawidis et al., 1995).

However, subsequent accumulation along the food chain is a potential threat to human health. Swain et al. (2014) recorded a similar trend (root $>$ leaves $>$ stem) of bioaccumulation of $\mathrm{Cd}$ in an experiment on the phytoremediation of $\mathrm{Cu}$ and $\mathrm{Cd}$ from water using $E$. crassipes. Also, Soltan and Rashed (2003) concluded that water hyacinth accumulated higher concentrations of heavy metals in the roots than in the aerial parts when the plant was treated with several heavy metals (Cd, $\mathrm{Co}, \mathrm{Cr}, \mathrm{Cu}, \mathrm{Mn}, \mathrm{Ni}, \mathrm{Pb}$ and $\mathrm{Zn}$ ).

Lead $(\mathrm{Pb})$ was recorded at a higher concentration compared to other metals analysed in the plant. The source of this metal could not be traced as the concentration was below detection limit in the water, sediment and fish. According to Ramachandra et al.
(2017), metal accumulation in aquatic plants depends on various factors including metal concentration in the environment, physical and chemical properties of sediments, contact time, condition of plant growth, absorption mechanisms and time of sampling. The findings of this study show that the sediment played an important role in accumulation of metals in plants. The higher accumulations of metals in sediments were directly responsible for the accumulation of heavy metals in E. crassipes.

The bioaccumulation factors (BAF) of heavy metals in fish in relation to water and sediment are presented in Figures 4 and 5. M. rume bioaccumulated $\mathrm{Zn}$ in relation to water at a higher concentration compared to other fish species. This was followed by $S$. mystus. $G$. niloticus, C. senegalensis and C. nigrodigitatus. High bioaccumulation of Nickel in $S$. mystus relative to sediment was observed in this study, while the bioaccumulation of $\mathrm{Fe}, \mathrm{Zn}$, and $\mathrm{Cr}$ in all fish species in relation to sediment was relatively low compared to that of fish to water.

Table 5: Concentrations of heavy metals in selected parts of some fish species in Lekki Lagoon 


\begin{tabular}{|c|c|c|c|c|c|c|c|}
\hline Fish species/Metals & Organ & Iron & Zinc & Cobalt & Chromiu & Cadmium . & Lead Nickel \\
\hline \multirow[t]{2}{*}{ Schillhe mystus } & $\begin{array}{l}\text { Liver } \\
\text { Gill } \\
\text { Muscle }\end{array}$ & $\begin{array}{l}0.303 \pm 0.15 \\
0.476 \pm 0.22 \\
0.417 \pm 0.69\end{array}$ & $\begin{array}{l}0.565 \pm 1.43 \\
0.75 \pm 0.04 \\
0.335 \pm 0.05\end{array}$ & $\begin{array}{l}\mathrm{BDL} \\
\mathrm{BDL} \\
\mathrm{BDL} \\
\end{array}$ & $\begin{array}{l}\text { BDL } \\
\text { BDL } \\
\text { BDL } \\
\end{array}$ & $\begin{array}{l}\text { BDL } \\
\text { BDL } \\
\text { BDL }\end{array}$ & $\begin{array}{ll}\text { BDL } & 0.12 \pm 0.01 \\
\text { BDL } & 0.08 \pm 0.00 \\
\text { BDL } & \text { BDL }\end{array}$ \\
\hline & Total & 1.196 & 1.65 & - & - & - & $-\quad 0.2$ \\
\hline \multirow[t]{2}{*}{ Moxmexus rwere } & $\begin{array}{l}\text { Liver } \\
\text { Gill } \\
\text { Muscle }\end{array}$ & $\begin{array}{l}0.426 \pm 0.28 \\
0.314 \pm 0.26 \\
0.311 \pm 0.17\end{array}$ & $\begin{array}{l}1.119 \pm 0.08 \\
0.622 \pm 0.01 \\
0.821 \pm 0.01\end{array}$ & $\begin{array}{l}\text { BDL } \\
\text { BDL } \\
\text { BDL }\end{array}$ & $\begin{array}{l}\text { BDL } \\
\text { BDL } \\
\text { BDL }\end{array}$ & $\begin{array}{l}\text { BDL } \\
\text { BDL } \\
\text { BDL }\end{array}$ & $\begin{array}{ll}\text { BDL } & 0.13 \pm 0.00 \\
\text { BDL } & 0.16 \pm 0.00 \\
\text { BDL } & \text { BDL }\end{array}$ \\
\hline & Total & 1.051 & 2.562 & & & & 0.29 \\
\hline \multirow[t]{2}{*}{ Giveraxchus viloticus } & $\begin{array}{l}\text { Liver } \\
\text { Gill } \\
\text { Muscle }\end{array}$ & $\begin{array}{l}0.612 \pm 0.29 \\
0.601 \pm 0.91 \\
0.195 \pm 0.36\end{array}$ & $\begin{array}{l}0.516 \pm 0.16 \\
0.653 \pm 0.38 \\
0.131 \pm 0.02\end{array}$ & $\begin{array}{l}\text { BDL } \\
\text { BDL } \\
\text { BDL }\end{array}$ & $\begin{array}{l}\text { BDL } \\
0.08 \pm 0.01 \\
\text { BDL }\end{array}$ & $\begin{array}{l}\text { BDL } \\
\text { BDL } \\
\text { BDL }\end{array}$ & $\begin{array}{ll}\text { BDL } & \text { BDL } \\
\text { BDL } & \text { BDL } \\
\text { BDL } & \text { BDL } \\
\end{array}$ \\
\hline & Total & 1.408 & 1.3 & & 0.08 & & \\
\hline \multirow[t]{2}{*}{ Gueglossus senegalensis } & $\begin{array}{l}\text { Liver } \\
\text { Gill } \\
\text { Muscle }\end{array}$ & $\begin{array}{l}0.633 \pm 0.35 \\
0.362 \pm 1.75 \\
0.323 \pm 0.29\end{array}$ & $\begin{array}{l}0.223 \pm 0.21 \\
0.619 \pm 0.23 \\
0.477 \pm 0.09\end{array}$ & $\begin{array}{l}\text { BDL } \\
\text { BDL } \\
\text { BDL }\end{array}$ & $\begin{array}{l}\text { BDL } \\
\text { BDL } \\
\text { BDL }\end{array}$ & $\begin{array}{l}\text { BDL } \\
\text { BDL } \\
\text { BDL }\end{array}$ & $\begin{array}{ll}\text { BDL } & \text { BDL } \\
\text { BDL } & \text { BDL } \\
\text { BDL } & \text { BDL } \\
\end{array}$ \\
\hline & Total & 1.318 & 1.319 & & & & \\
\hline \multirow[t]{2}{*}{ Chxysichthys vigredigitotus } & $\begin{array}{l}\text { Liver } \\
\text { Gill } \\
\text { Muscle }\end{array}$ & $\begin{array}{l}0.362 \pm 0.48 \\
0.465 \pm 0.57 \\
0.150 \pm 0.09\end{array}$ & $\begin{array}{l}0.140 \pm 0.02 \\
0.852 \pm 0.37 \\
0.130 \pm 0.07\end{array}$ & $\begin{array}{l}\text { BDL } \\
\text { BDL } \\
\text { BDL }\end{array}$ & $\begin{array}{l}\text { BDL } \\
\text { BDL } \\
\text { BDL }\end{array}$ & $\begin{array}{l}\text { BDL } \\
\text { BDL } \\
\text { BDL }\end{array}$ & $\begin{array}{ll}\text { BDL } & \text { BDL } \\
\text { BDL } & \text { BDL } \\
\text { BDL } & \text { BDL } \\
\end{array}$ \\
\hline & Total & 0.977 & 1.122 & & & & \\
\hline PM & & 43 & $10-75$ & & $0.15-1.0$ & & $0.5-0.6$ \\
\hline
\end{tabular}

*BDL=Below Detection Limit, $B D L=$ Not Detected.

Table 6: Heavy metal concentrations (mg/kg) in Eichhornia crassipes in lagoon of Lekki Lagoon

\begin{tabular}{llll}
\hline Metals (mg/Kg) & Root & Stem & L eaves \\
\hline $\mathrm{Fe}$ & 2.03 & 0.27 & 1.03 \\
$\mathrm{Zn}$ & 7.09 & 1.21 & 5.02 \\
$\mathrm{Co}$ & $\mathrm{ND}$ & $\mathrm{ND}$ & $\mathrm{ND}$ \\
$\mathrm{Cr}$ & 4.08 & 2.65 & 3.87 \\
$\mathrm{Cd}$ & 0.59 & $\mathrm{ND}$ & 0.23 \\
$\mathrm{~Pb}$ & 8.54 & 5.46 & 0.088 \\
$\mathrm{Ni}$ & 0.632 & 0.8 & $\mathrm{ND}$ \\
\hline
\end{tabular}

$P M=$ Permissible limits (FAO, 1983; WHO, 1985, 1994; FEPA, 2003)

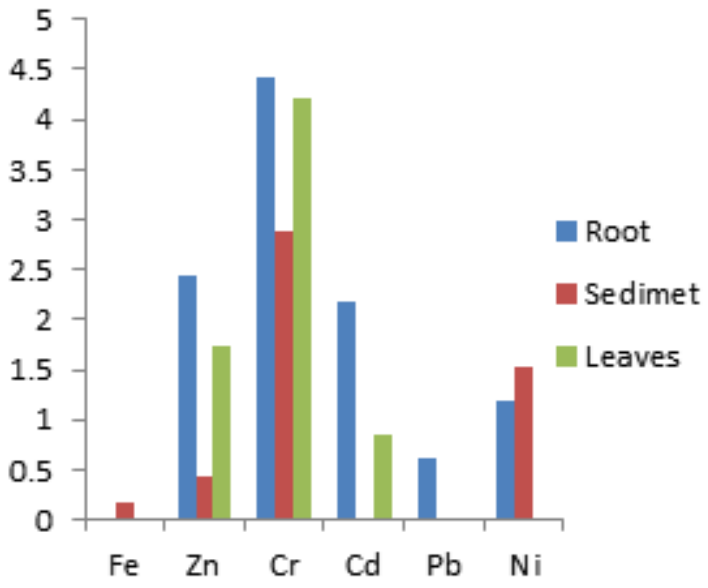

Fig. 2: Bioaccumulation factor of heavy metal in Eichhornia crassipes in relation to sediment

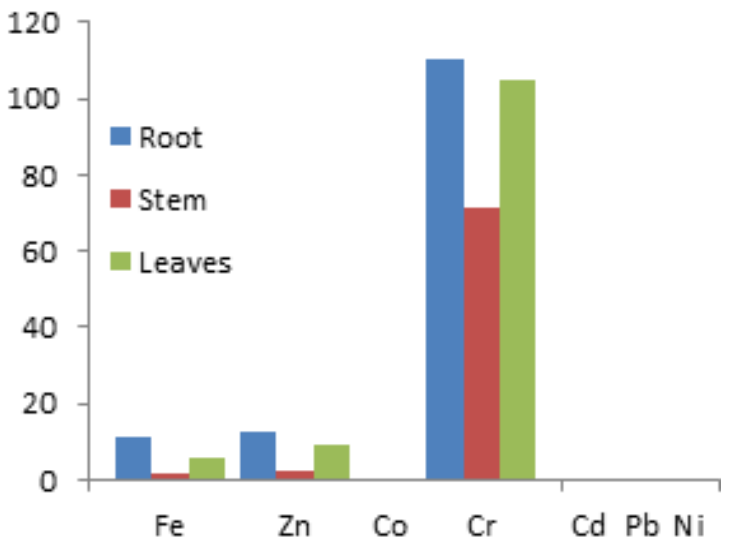

Fig 3: Bioaccumulation factor of heavy metals in Eichhornia crassipes in relation to water in Lekki Lagoon

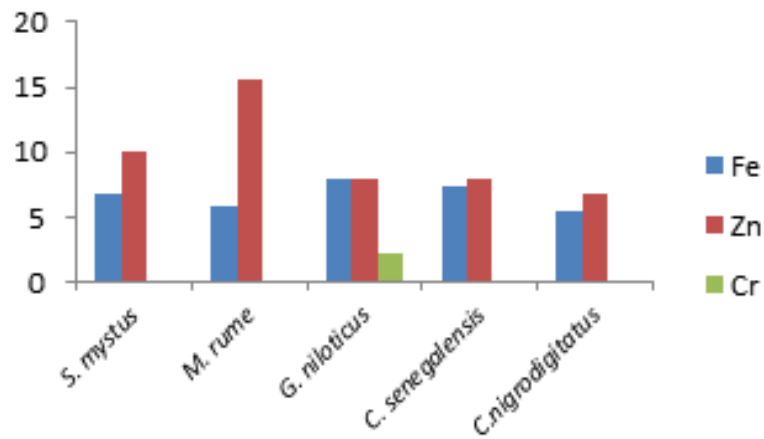

Fig. 4: Bioaccumulation factor of heavy metal in in fish in relation to water 


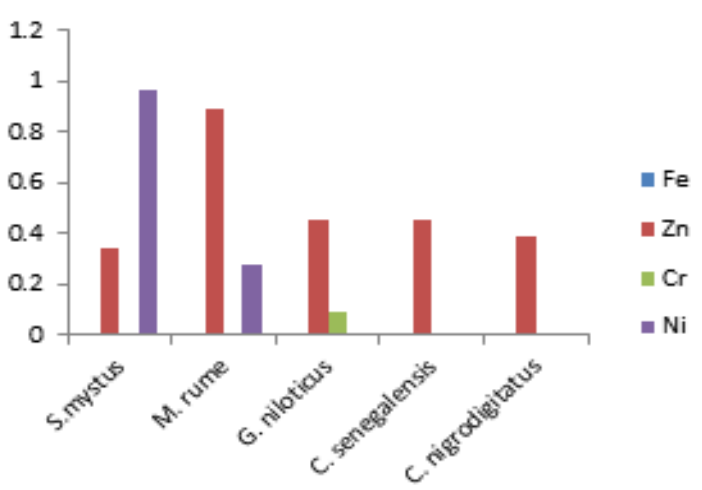

Fig. 5: Bioaccumulation factor of heavy metal in in fish in relation to sediment

Conclusion: Heavy metals are present in varying concentrations in the sediment, water, fish and aquatic macrophytes (Eichhornea crassipes) in Lekki lagoon, a Tropical lagoon in the Gulf of Guinea in West African coastline. The presence of these metals is, however, within the permissible limits in the fish species and water sampled but above permissible limits in the sediment and well accumulated in the plant.

In view of the importance of fish as food for man and the safety of human health, it is important to periodically monitor the concentrations of heavy metals in the Lagoon in order to prevent any health hazards and maintain ecological processes along the Gulf of Guinea of the Atlantic Ocean.

\section{REFERENCES}

Abeh, T; Gunshik, J; Adamu, MM (2007). Separation studies of trace elements level in sediment from Zarmaganda stream in Jos, Plateau state, Nigeria. Journal of the Chemical Society. 32(2):218 -24

Adebayo, IA (2017): Determination of Heavy Metals in Water, Fish and Sediment from Ureje Water. Fish \& Ocean Opj. 4(1): 1-11

Aderionla, OJ; Clarke, EO; Olarinmoye, OM; Kusemiji, V; Anatekhai, MA (2009). Heavy metals in surface waters, sediments, fish and periwinkles of Lagos lagoon. American-Eurasian Journal of Agricultural and Environmental Sciences. 5(5): 609-617

Akan, JC; Mohmoud, S; Yikala, BS; Ogugbuaja, VO (2012). Bioaccumulation of some heavy metals in fish samples from River Benue in Vinikilang, Adamawa State, Nigeria. American Journal of Analytical Chemistry, 3:727-736.
Akhiromen; DI; Ogbonne, FC (2018). Biochemical Responses and Heavy Metal Accumulation in Macrobrachium vollenhovenii in Epe axis of Lekki Lagoon. Bells University Journal of Applied Sciences and Environment (BUJASE), 1(1): 63-72

Arena, G; Copat, C; Fallico, R; Ferrante, M; Fiore, M; Ledda, C. and Sciacca, S. (2013). Heavy metals concentrations in fish and shellfish from eastern mediterranean sea: Consumption advisories. Food and Chemical Toxicology. Elsevier, 53: 33-37

Asaolu, SS; Olaofe, O (2004). Biomagnification factors of some heavy and essential metals in sediment, fish and crayfish from Ondo State Coastal region. Biophysical Research Communications. 16: 33-35

Asaolu, SS; Ipinmoroti, KO; Olaofe, O; Adeeyinwo, CE (1997). Seasonal variation in heavy metals in sediment from Ondo State Coastal area. Ghana Journal of Chemistry, 3:11-14

Burger, J; Gochfield, M. (2005). Heavy metals in commercial fish in New Jersey. Environmental Research, 99(3): 403-412

Celo, V; Babi, D; Baraj, B; Cullaj, A. (1999). An assessment of heavy metal pollution in the sediments along the Albanian coast. Water, Air, and Soil Pollution, 111: 235-250

Chindah, AC; Braide, SA; Sibeudu, OC (2004). Distribution of Hydrocarbons and heavy metals in sediment and a crustacean shrimps- Penaeus notialis from the Bonny/ New Calabar River Estuary, Niger Delta. A JEAM-RAGEF. 9:1-17

Davies, OA; Allison, ME; Uyi, HS (2006). Bioaccumulation of heavy metals in water, sediment and periwinkle (Tympanotonus fuscatus var radula) from the Elechi Creek, Niger Delta. African Journal of Biotechnology. 5 (10): 968-973

Don-Pedro, KN; Oyewo, EO; Otitoloju, AA (2004). Trend of heavy metal concentration in Lagos Lagoon ecosystem, Nigeria. West African Journal of Applied Ecology, 5: 103-114

DPR (2002). (Department of Petroleum Resources) Environmental Guidelines and Standards for the Petroleum Industry in Nigeria (EGASPIN) Nigeria: Taylor \& Francis; pp203 
Eddy, NO; Udo, CL; Ukpong, IJ (2004). Heavy metals in sediment from the Cross river at Oron. African Journal of Environmental Pollution and Health, 3(5): 21-26

Edokpayi, JN; Odiyo, JO; Popoola, OE; Msagati, TA (2016). Assessment of Trace Metals Contamination of Surface Water and Sediment: A Case Study of Mvudi River, South Africa. Sustainability, 8:135-148

Ekpo, FE; Agu, NN; Udoakpan, UI (2013). Influence of heavy metals concentration in three common fish, sediment and water collected within quarry environment, Akamkpa 1 .g. area, Cross River State, Nigeria. European Journal of Toxicological Sciences. 3: 52-64

Emmanuel, B. E; Chukwu, LO; (2010). Spatial distribution of saline water and possible sources of intrusion into a tropical freshwater lagoon and the transitional effects on the lacustrine ichthyo faunal diversity. African Journal of Environmental Science and Technology. 4(7): 480-491.

FAO (1983): Compilation of legal limits for hazardous substances in fish and fishery products. FAO Fishery Circular, 464:5-100

Federal Environmental Protection Agency (FEPA). (1991). International Guidelines and Standards INDustrial effluents gaseous emission and hazard waste management in Nigeria. Federal Environmental Protection Agency Publication, Lagos, Nigeria. 210Pp

FEPA (2003). Guideline and Standards for Environmental Pollution and Control in Nigeria. Federal Environmental Protection Agency, Nigeria. $288 \mathrm{Pp}$

FEPA (2003). (Federal Environmental Protection Agency) Guidelines and Standards for Environmental Pollution Control in Nigeria. Nigeria: Taylor \& Francis; Forstner, U; Witlmann, GTW. (1979). Metal pollution in the aquatic Environment, Berlin, Springer-Verlag.

Jonah, A; Solomon, EI; and Ano, AO (2014). Study on the physicochemical properties and heavy metal status of sediment samples from OhiiMiri river in Abia State, Nigeria. Fountain Journal of Natural and Applied Sciences. 3(1): 29-43.

Kuton, M; Akinsanya, B; Saliu, JK; Ukwa, UD; (2014). Relevance of intestinal helminth parasites of Channa obscura and Sarotherodon melanotheronon host metal accumulation in Lekki lagoon, Lagos, Nigeria. Unilag Journal of Medicine, Science and Technology, 125-136.

Li, J (2014). Risk Assessment of Heavy Metals in Surface Sediments from the Yanghe River, China. Environmental Research and Public Health. 11:12441-12453.

Milena, M; Sobiecka, E. (2017). The efficiency of macrophytes for heavy metals removal from water. Biotechnol. Food Sci. 81(1): 35-40

Murtala, BA; Abdul, WO; Akinyemi, AA (2012). Bioaccumulation of heavy metals in fish (Hydrocynus forskahlii, Hyperopisus bebe occidentalis and Clarias gariepinus) organs in downstream Ogun coastal water, Nigeria. Transnational Journal of Science and Technology. 2(5): 121-133.

Nazir, R; Khan, M; Masab, M; Ur Rehman, H; Ur Rauf, N; Shahab, S; Ameer, N; Sajed, M; Ullah, M; Rafeeq, M; Shaheen, Z (2015). Accumulation of Heavy Metals ( $\mathrm{Ni}, \mathrm{Cu}, \mathrm{Cd}, \mathrm{Cr}, \mathrm{Pb}, \mathrm{Zn}, \mathrm{Fe}$ ) in the soil, water and plants and analysis of physicochemical parameters of soil and water Collected from Tanda Dam kohat. Journal of Pharmaceutical Sciences and Research. 7(3):8997.

Nussey, G (2000). Bioaccumulation of Chromium, Manganese, Nickel and Lead in the Tissues of the Moggel, Labeo um- bratus(Cyprinidae), from Witbank Dam, Mpumalanga, Water SA. 26(2): 269-284,

Nwajei, GE; Gagophien, D (2000). Distribution of heavy metals in the sediments of Lagos Lagoon, Pakistan Journal of Scientific and Industrial Research, 43: 338-340.

Ogoyi, DO; Mwita, CJ; Nguu, EK; Shiundu, PM (2011): Determination of Heavy Metal Content in Water, Sediment and Microalgae from Lake Victoria, East Africa. The Open Environmental Engineering Journal. 4: 156-161

Olusola, JO; Festus, AA (2015). Assessment of Heavy Metals in Some Marine Fish Species Relevant to their Concentration in Water and Sediment from Coastal Waters of Ondo State, Marine Science Research and Development. 5(2): 163-169

ABDUL, WO; OGUNTUASE, KE; OMONIYI, IT; BADA; SB; ADEKOYA, EO; BASHIR, AO; IBEBUIKE, LC; $O P A J O B I, G A$ 
Onyari, JM; Wandiga, SO (1989): Distribution of Cr, $\mathrm{Pb}, \mathrm{Cd}, \mathrm{Zn}, \mathrm{Fe}$ and $\mathrm{Mn}$ in lake Victoria sediment, East Africa, Bulletin of Environmental Contamination and Toxicology. 42: 807-813

Opadokun, I.O., Falaye, A.E. and Ajani E.K. (2015). Seasonal variations in physicochemical parameters of Lakki lagoon and the conservation of its ecosystem. Journal of Geoscience and Environmental Protection, 3:11-17

Page, AL; Miller, RH; Kenney, DR (1982). Heavy metals determination. In: Methods of Soil Analysis, Part 2, Chemical and Microbiological Properties. American Society of Agronomy, Madison, WI, USA. 8pp.

Ramachandra, TV; Sudarshan, PB; Mahesh, MK; Vinay, S (2017): Spatial patterns of heavy metal accumulation in sediments and macrophytes of Bellandur wetland, Bangalore. Journal of Environmental Management. 10:1-17

Samecka-Cymerman, A; Kolon, K; Kempers, AJ (2005). "Differences in concentration of heavy metals between native and transplanted Plagiothecium denticulatum: a case study of soils contaminated by oil well exudates in south east Poland" Archives of Environmental Contamination and Toxicology. 4(317-321).

Santos, IR; Silva-Filho, EV; Schaefer, CE; Albuquerque- Filho, MR; Campos, LS (2005). Heavy metals contamination in coastal sediments and soils near the Brazilian Antarctic Station, King George Island. Marine Pollution Bulletin; 50: 85194.

Sawidis, T; Chettri, MK; Zachariadis, GA; Siratis, JA (1995). Heavy metals in aquatic plants and sediments from water systems in Macedonia, Greece. Ecotoxicology and Environmental Safety. 32:73-80
Shukla, V; Dhankhar, M; Prakash, J; Sastry, KV (2007). Bioaccumulation of $\mathrm{Zn}, \mathrm{Cu}$, and $\mathrm{Cd}$ in Channapuntatus. Journal of Environmental Biology; 28:395-397.

Soltan, ME; Rashed, MN (2003). Laboratory study on the survival of water hyacinth under several conditions of heavy metal concentrations. Advances in Environmental Research. 7: 321-334.

Swain, G; Adhikari, S; Mohanty, P (2014). Phytoremediation of copper and cadmium from water using water hyacinth, Eichhornia crassipes, International Journal of Agricultural Science and Technology (IJAST). 2(1):1-6.

Taweel, A; Shuhaimi-Othman, M; Ahmad, AK (2013). Assessment of heavy metals in tilapia fish (Oreochromis niloticus) from the Langat river and Engineering lake in Bangi, Malaysia, and evaluation of health risk from tilapia consumption. Ecotoxicology and Environmental Safety. 93: 4551.

WHO (1994). Guidelines for drinking water quality recommendation. World Health Organization Geneva

WHO (1985) Guidelines for Drinking Water Quality Health Criteria and Supporting Information. Vol. 1, Recommendations. WHO, Geneva. 130Pp.

World Health Organization (2003). Guidelines for Drinking Water Quality.Geneva, 2: 130Pp.

WHO (2008). World Health Organisation. Guidelines for Drinking Water Quality; World Health Organization: Geneva, Switzerland,

Yabanlı, M; Yozukmaz, A; Sel, F (2014): Heavy Metal Accumulation in the Leaves, Stem and Root of the Invasive Submerged Macrophyte Myriophyllum spicatum L. (Haloragaceae): An Example of Kadın Creek (Mugla, Turkey) Brazilian Archives of Biology and Technology. 57(3): 434-440 